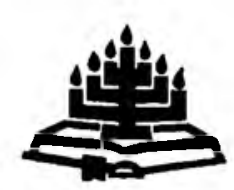

\title{
Preaching as topical communication: The case of Calvin ${ }^{1}$
}

\author{
L.F. Schulze \\ Department of Dogmatology and Ecclesiology \\ Potchefstroom University for $\mathrm{CHE}$ \\ POTCHEFSTROOM
}

\begin{abstract}
Preaching as topical communication: The case of Calvin

Because of the enmity and even persecution of Protestants by the Roman Church and Roman states during the Reformation, the conduct of Protestants in Roman countries became a topical issue - indeed an existential issue of life or death. In these circumstances many Protestants tried to compromise their faith by partaking externally in the Roman rites, especially the Mass and parochial Mass, in order to safeguard their existence. The first of the Four Sermons (Quatre sermons, 1552), addressing this existential question, is presented as an example of the topicality of Calvin's preaching. Hoving analysed some key words in Calvin's exposition and application of his text (Ps. 16:4-6) it is concluded (a) that Calvin puts the Gospel squarely in the midst of the daily life of his congregation, (b) that his accent on the body contradicts the popular notion of Calvin's "spiritual tendency" and (c) his rejection of the Mass rests on the biblical message of the unique atonement of Christ, once and for all.
\end{abstract}

\section{Introduction - an existential question}

The religious and social upheavals of 16th century Europe created for many a psychological disarray and uncertainty, which we can hardly visualize today. Battle lines were drawn clearly and acrimoniously. The Romanists saw Protestant convictions as a novel doctrine, against common sense, at odds with tradition, and pernicious in its abolition of all piety (Pighius, 1542:1-2). They mobilized their ecclesiastical tribunals and the military power of Roman states to uproot this heresy. Protestants, on the other hand, branded Roman hierarchy as a

1 Paper delivered at the centenary of the Zwingli Society in Zürich, 29 October - 2 November 1997.

In die Skrlflig 32(2) 1998:115-126 
degeneration of true apostolic (doctrinal) succession, its doctrine as a deformation of Scriptural truth, and its ritual as rife with superstition. For a summary of Calvin's views as expressed in his tracts see Torrance (1958:vii-xi and xxxviii-xl - henceforth quoted as Calvin's Tracts). In this article the term Protestant is preferred in this context instead of Evangelical, which is a wider term and can include the left wing spiritual groups (i.a. the Anabaptists), who, in their turn, have distanced themselves from the "magesterial Reformation" of Protestantism (see Williams, 1962).

To Protestants living in predominantly Roman countries their turbulent situation posed an acute, existential question: How to live and to survive in these dangerous circumstances? It is noteworthy that the reverse does not hold. See Wallace (1988:81), who quotes Karl Holl that never "at any time whatsoever did the Protestant states brand a Catholic a 'heretic' for his faults, let alone punish him". The only exceptions (e.g. in England) were all politically motivated. The dilemma is obvious: Either they could openly profess their faith, thereby risking captivity and even death, or they could keep quiet, disseminate the Protestant faith secretly to others, and go through the motions of the Roman rites.

The existential question ("to be or not to be") was endemic in Westem Europe during the greater part of the 16th century, and Calvin was often asked for his advice. He gave advice on various occasions, the first time as early as 1537 when he wrote On Shunning the Unlawful Rites of the Ungodly and Preserving the Purtty of the Christian Religion. (English translation in Calvin, 1958, 3:359-411.) This tract has a subtitle, "A letter by John Calvin to his dear and very excellent friend, N.S.", and is indeed cast in the form of an open letter. In his Life of Calvin Beza (1958, I:lxix) tells us that this letter was addressed to Nicholas Chemin, and that Calvin wrote in the same year another tract on the same topic, Popish Priesthood, addressed to Gerard Roussel. Continual requests for advice from Protestants in France led to the Petit Traicté (1543), an extensive exposition of his view of the deformation of the Roman Church, and the way in which Protestants should conduct their lives in a Roman country. ${ }^{2}$ This treatise evoked criticism to which Calvin answered with an apology, Excuse de Jehan Calvin à Messieurs les Nicodemites (1544). (See Kayayan's English translation - Calvin, 1994.)

Five years later (1549), during his Sunday sermons on Hebrews (mornings) and the Psalms (afternoons), ${ }^{3}$ he occasionally returned to this pressing question to restate his advice.

2 "Petit Traicté monstrant que c'est que doit faire un homme fidèle congnoissant la verité de l'evangile quand il est entre les papistes" (CO. 6, 537-588). 


\section{The Four Sermons}

Perhaps the most convincing indication of the urgency of this existential issue and, consequently, of the topicality of Calvin's preaching is found in the publication of the Four Sermons. ${ }^{4}$ These four sermons (with an added exposition of Psalm 87), "very profitable for our time", were selected from the series preached on Sundays during 1549, and consist of the sermons on Ps. 16:4-6, Hebr. 13:13, Ps. 27:4 and Ps. 27:8. They were the first sermons of Calvin to be published, and the only ones to be revised and prepared for publication by Calvin himself. Calvin was an extemporary preacher and these four sermons were among the first recorded by Denis Raguenier ( 6000 words in an hour!) - 40 years before the first modern method of short hand appeared in print (Parker, 1992:66-67). What Parker remarks about Calvin's writings applies also to these sermons:

Calvin's style as extemporary preacher is markedly different from that which we find in his French writings. There he displays the virtues that make him one of the great French masters and a moulder of modern French. But here, in the [extemporary] sermons, he deliberately adapts his style to the grasp of the common people in his congregation (Parker, 1992:148). 5

The sermons can be divided into two pairs. The first two sermons are primarily intended for Protestants living in predominantly Roman territories and consist of a) a stern admonition to refrain at all costs from taking part in the idolatrous Roman rites, and b) a more consoling sermon, urging them to be steadfast amidst all temptations. The last two sermons are directed to the Genevans themselves, exhorting them to be worthy of the singular grace to worship God according to the precepts of his Word. (See Calvin's preface (CO 8, 375-376); Peter, 1984:2526.)

Bearing in mind the unsettled political and social background and the existential issue that confronted so many Protestants, the publication of the Four Sermons is a testimony to Calvin's sense of topical communication.

Another impressive example of preaching as topical communication is found in the sermon that Calvin preached on Acts 20:17 ff. The date was Sunday, Sept. 3, 1553 (cf. Parker, 1992:151). The occasion was the celebration of the Lord's Supper. Present in the church was Philibert Berthelier who had been excommunicated by the Consistory in 1551 but had, shortly before, obtained permission by the General Council to partake in Holy Communion. At stake,

4 "Quatre sermons traictans des matieres fort utiles pour nostre temps, acev briefve exposition du Pseaume 87" Robert Estienne, 1552 (CO 8, 369-452)

5 Cf. Peter, 1984:24, who also points to the different style of the Four Sermons and says, "Calvin nous y livre un des morceaux oratoires les plus vigoureux et les plus véhéments qui soient sortis de sa plume..." 
therefore, was the independence of the church in matters of disciphne. Unfortunately, this sermon is not extant in print. Beza, however, tells us that Calvin preached in such a way that Berthelier did not dare come forward. He says that Calvin, "raising his voice and his hand in the course of his sermon ... exclaimed, in the words of Chrysostom, 'I will die sooner than this hand shall stretch forth the sacred things of the Lord to those who have been judged despisers'. These words, strange to say, had such an effect upon these men, however lawless, that Perrin secretly advised Berthelier not to come forward to the Table"6.

\section{Narrowing the focus}

\subsection{The first of the Four Sermons}

In the first sermon, the only one to have our attention, we see Calvin the jurist at his best. With meticulous arguments he invalidates the excuses and subterfuges of his opponents. Judged by current homiletic standards the sermon might be seen as out of balance - too little exegesis and too much application. In the Dutch translation by Douma and Van der Vegt (1941:5:11-30) the exposition of Psalm 16:4-6 comprises barely more than a page while the application and exhortation cover almost seventeen pages. However, in the application a host of other biblical texts (e.g. Dan. 3; 1 Cor. 6:20; 7:23; Eph. 5:30; Jer. 10:11; Is. 44:8, etc.) come into play. What is particularly interesting and deserves our attention is the way in which certain exegetical key words recur in the rest of the sermon, integrating the sermon as a unity. (Note the relevant remarks of Parker (1992: 132): "The form of his preaching is determined by the movement of the text", and: "the sermons are like rivers, moving strongly in one direction, alive with eddies and crosscurrents".)

\subsection{The exposition of the text}

After a short summary ${ }^{7}$ of the pure doctrine, Calvin addresses, first of all, the Genevans who thought it superfluous to be taught that Protestants should avoid

6 Calvin's Tracis, 1:ci Cf. also Hughes (1966:11-13); $R C P$ p. 205, 285-289, 291, 293; Wallace, (1988:61-62). From the abundance of examples of the topicality of Calvin' preaching (some noted by Parker, 1992), only one additional case is mentioned in passing: his painful reaction to the profanation of the Psalms by a gang of youths in January 1555 (cf. CO 53, 405; Peter, 1984: 37).

7 La somme est, qu'apres avoir cogneu le Dieu vivant pour nostre pere, et Jesus Christ pour nostre redempteur, nous debvons dedier corps et ame à celuy qui par sa bonté infinie nous a adoptez pour ses enfans, et mettre peine à faire hommage à ce bon Sauveur de ce qui luy a cousté si cher. Et pourtant, que nous avons non seulement à renoncer à toute infidelite, mais aussi à nous separer de toutes superstinons qui sont contraires tant au service de Dieu qu'a l'honneur de son Fils, et lesquelles ne se peuvent accorder avec la pure doctrine de l'Evangile et la vraye 
Roman ceremonies. They based their objection on the fact that in Geneva they had the liberty to worship according to the gospel. Having refuted their arguments, Calvin concludes:

We see then that it is profitable, indeed even necessary, for us as well as for our brothers that the knowledge of this doctrine should often be refreshed, and especially when the text we have to expose leads us in that direction ( $\mathrm{CO} \mathrm{8,} \mathrm{378-}$ 379 - my translation: LFS).

In this way, by addressing his congregation, Calvin comes to his text. In the Authorized Version Psalm 16:4(b) reads as follows: "Their drink offering of blood I will not offer, nor take up their names into my lips". 8

In this passage, says Calvin, David professes most surely, as with a solemn oath, never to participate in the sacrifices of idolaters, even to hate and detest idols to such extent that he will abstain from naming them as if he would befoul his mouth by doing so. This is not simply a particular act of one person but an example to be followed by all God's children. Calvin often stressed this idea. See Opitz, (1997:126), who remarks about Calvin's sermons on Ps. 119: "Der Psalmdichter David vollzieht diese Zuwendung zu Gott in für uns exemplarischer Weise. Er ist uns als 'Vorbild' gegeben ... Er ist von Gott zu einer Art 'Spiegel für alle Glaubenden' gemacht ...".

To accentuate this more clearly and forcibly we must note David's addition of the reason for his aversion to idols. "The Lord is my heritage", he says. Has David not this in common with all believers? Indeed, since God has once given himself to us in the person of his Son, he will daily urge us to have him as our portion. Because of this heritage, David has good reason to abstain from any defilement with idolaters - defilement which estranges us from the Lord. Therefore Isaiah (57:6), accusing the Jews of surrendering themselves to their self-created idols, adds, "They are your portion, they are your lot", thereby intimating that God cuts off all ties with idolaters. In whichever way we approach idols (by conviction, custom, free will, or pretence), in that same measure we become alienated from God

In his colloquial way Calvin finally drives home the essence of the text by saying that we should hold it as irrefutable that they who truly seek to possess the Lord as their heritage will have nothing to do with idols. Note, says Calvin, that David expressly states that he will not participate in their offerings, nor take their names

confession de foy $(\mathrm{CO} 8,377$; my emphasis - LFS). This summary is a prefiguration of what Calvin finds in the text

8 Fr.: le ne communiqueray point à leurs sacrifices de sang, et leur noms ne passeront point par ma bouche ("I will have no communion with their libations ..."). In the French tex this was verse 3 (Douma \& van der Vegt, 1941:11, note 1) 
upon his lips. David could have said, "I will not abuse myself with the silly devotion of the infidels; I will not put my confidence in such abuses; I will not desert the truth of God to follow such lies. However, he does not speak in this way, but states that he will not mingle in their ceremonies. Therefore, as regards the service of God, he professes to keep himself pure in body and soul" (CO 8, 379-380, my translation - LFS).

\subsection{Some key words}

Some key words present in the initial summary of the doctrine have already been emphasized. These key words include: to dedicate body and soul to him who has adopted us, to pay homage to the Saviour - which entails: to renounce all infidelity and to abstain from all superstitions, which are incompatible with the service of God, the honour of his Son, the pure doctrine, and the true confession of faith.

In the exegesis the following ideas are stressed: not to take part in the sacrifices of idolaters; not to mention the names of idols; God is our heritage - therefore, we totally belong to him. David's refusal to take part in their offerings and to mingle in their religious ceremonies is accentuated by Calvin. He concludes his exposition with a statement that closes the circle by restating elements from the initial summary, viz. to keep body and soul pure in the service of God. ${ }^{9}$ Calvin often stressed this idea, intimating that while man has a body, the outward "form" of the church and its liturgy is by no means indifferent (cf. his letter of Oct. 1541 to the Duchess of Ferrara, quoted by Wallace, 1988:134)

In the following section attention is only paid to the key words body and offering. ${ }^{10}$

\section{A few strides through the application}

During the course of his sermon Calvin speaks to six discernible categories of people. In one way or another five of them object to the profitability or the implications of the true doctrine. The sixth category of people do not object but simply remain impassive in their situation cf. CO 8, 391: Quant aux autres, qui ne reiectent point la parolle de Dieu en telle fierté ...). Calvin urges them to steel themselves and be steadfast. To the first category of people belong the Genevans who deem the doctrine superfluous, and to whom reference has already been made. The second group argues (with tongue in cheek) that it is no big issue to

9 Il proteste donc de se maintenir en purité de corps comme d'ame quant au service de Dieu (CO 8, 380).

10 It is not possible to render a sensible resume of Calvin's sermon within the scope of this article Therefore the restriction to a few key words. 
take part in Roman rites. The third categorically denies participation in Roman ceremonies to be a sin. Others (belonging to the fourth category) concede that idolatry is a horrible sin but deny that Roman superstitions are idolatrous. Finally, there are those who abstain from the Mass but keep to other ceremonies in order not to appear irreligious. ${ }^{11}$

Having commented on the text, and before addressing the second category of objectors, Calvin starts his application with a general question which sets the trend of the rest of the sermon: "In the first place we have to see whether it is idolatry to show by outward signs that one agrees with the superstitions by which the service of God is corrupted and perverted".12 This means that the service of God is the overarching theme in which body (i.e. "outward signs") and offering are encapsulated.

Persons of the second category are the compromisers who want to serve God but regard participation in Roman ceremonies a minor sin. They argue that God wants to be worshipped in spirit. Therefore, one cannot worship idols if one does not put one's trust in them.

Indeed, says Calvin, but this does not mean that the external (visible) behaviour is irrelevant, for to bow and to lift up the hands are often mentioned in the Bible. And what about Daniel and his friends who refused to worship the image erected by Nebuchadnezzar? If these good sophists were there, they would have mocked these three servants of God: poor rascals, it is no worship if you don't attach any faith to it!

Calvin, the pastor, tries to convince the compromisers that participation in Roman ceremonies, if only by means of external pretence, is no small matter but a display of disloyalty. It is an act that contradicts the confession of faith - that solemn pledge we have made. When we violate this pledge we are also violating the honour of God, thereby proving ourselves cowards who openly desert our Christianity. In his sermon on 2 Timothy 3:16-17, Calvin explains why the minister sometimes has to use harsh words; that reproof is not enough but must be accompanied by correction: “... that is, that we may be, so to say, chastised by God's Word, to reform us, so that we may be drawn out of our vices" (CO 54,

II Note the expressions which indicate the five groups. (1) Mais pource qu'aucuns pensent que ce soit un argument superflu quant à nous ... (CO 8, 377); (2) Ceulx qui nagent entre deux eaues ... (CO 8, 380); (3) Il y en a des autres qui sont plus effrontez ... (CO 8, 381); (4) Il y en a qui usent auiourd 'huy d'une autre eschappatoire ... (CO 8, 383); (5) Il y en a d'autres qui viennent iusques là de quicter la Messe ... (CO 8, 388)

12 CO 8, 380: En premier lieu, nous avons yci à veoir si c'est idolatrie de monstrer par signes exterieurs qu'on s'accorde aux superstitions par lesquelles le service de Dieu est corrompu et perverti 
290; Parker's translation, 1992:14). In his prayer at the end of the homily on Malachi 2.13-16 a petition for fidelity to our pledge (confession) appears: “... but suffer and bear with us kindly, and at the same time strengthen us that we may persevere in the truth and perform to the end the pledge we have given to thee, and which thou didst require from us in our baptism ..." (Calvin, 1979:562).

When dealing with the third category of objectors the significance of the body in worship is treated more explicitly. These people argue that to take part in the Roman rituals is no sin at all, for God demands of us nothing more than to serve him with our heart.

Calvin concedes that the last part of their statement is true, provided that we are not double-minded. When there is true integrity, the body will not act in the opposite way. I want to ask them, continues the preacher, Who directs their feet to the church to hear Mass? Their legs never move by themselves. Therefore they must have some desire to mingle in the idolatry. 13

Along these lines Calvin communicates with this group of people. A few more points from Calvin's sermon regarding the body, are mentioned - arguments by means of which he refutes their argument.

- We must worship God in spirit. Yes, but to whom belongs the body? Paul urges us to glorify the Lord in both, since both belong to him (1 Cor. 6:20).

- How are we to expect the resurrection of the flesh if Christ is not the Redeemer of body and soul? It is stated that our body is a temple of the Holy Spirit and that we are members of the body of Christ (Eph. 5:30), which means that we are, body and soul, united with him. Therefore, one can not defile his body with some or other superstition without withdrawing him from this sacred union by which we became members of the Son of God. Let these subtle teachers answer me whether they have received baptism only in their soul. Did God not ordain that it should be a sign engraved in our flesh? Is the Lord's Supper received only by the soul, and not also by hand and mouth?

By means of a striking metaphor Calvin drives home his argument:

- It is illegal to imprint two seals on one gold coin or to superimpose two different seals on the same official document. Will mortal man then plead not guilty when he falsifies the baptism and Supper of the Lord? (See for the argument $\mathrm{CO} 8,381: 382$.)

13 Cf. Zwingli's remark (Samtliche Werke, vol. 4, p. 127), "The weaker in faith that a man is, the sooner he succumbs to idols" (quoted by G W. Locher, 1981:5, note 10). 
We finally mention some aspects of Calvin's argument against those (the fourth category) who admit that idolatry is abhorrent but who deny that it is apphcable to the Roman ceremonies. In this context the textual key word offering comes to the fore.

- All forms of idolatry, says Calvin, are deformations of true worship prescribed in the Law. The two golden calves made by King Jerobo'am illustrate the point. It is clear that the Papal Mass and the Lord's Supper are as incompatible as the offerings of Moses and those of Jerobo'am. Why then, can people go to Mass with the pretence that it is simply a variation (disguisement) of the Lord's Supper? (CO 8, 383).

- Calvin proceeds: The Mass is a denial of the death of Christ. "I will speak more directly: 14 The Mass is a sacrifice by which the Papists want to offer Jesus Christ to reconcile them to God". 15

- There are, however, some of these people who do not join in the celebration of the Mass. Instead they attend the parochial Mass, which, to their mind, is more closely related to the Protestant celebration of Holy Communion. Calvin disagrees. The parochial Mass, he states, is like a woman of questionable morals who covers herself with her husband's name in order to pass as reputable. There is no trace of similarity between the parochial Mass and the Lord's Supper. On the contrary, the parochial Mass is the most common idolatry accessible to all. In fact, the parochial Mass is instituted to sacrifice Jesus Christ and to effect reconciliation to God on behalf of the living and the dead. (Cf. for these arguments against the fourth category - $\mathrm{CO} 8,383-386$.)

\section{Summary}

We have taken a few strides through the sermon without touching Calvin's address to those we have termed categories five and six. Our chosen key words are indeed not so prominent in the last pages of the sermon. However, it is worth remembering that Calvin turns towards a positive note at the end of his sermon. What are we to do, he asks. The answer is that we should serve God with buming zeal and shun everything that tends to dishonour him. In addition he exhorts his readers to remain steadfast and to regard their lives as less in value compared to the truth of the Gospel and honour of God.

14 le parleray encores plus priveement (CO 8,385). Priveement has the meaning of in particular, or intimately (sec the glossary in Benoit, 1963:452).

15 La Messe est un sacrifice auquel les Papistes veulent offrir Iesus Christ pour se reconcilier à Dieu (CO 8, 385). However, note the change of case in Paul's statement (2 Cor 5:18), “.. God, who through Christ reconciled us to himself ." 
Following his exposition of the text, Calvin has raised the fundamental question, viz. whether it is idolatry when one shows by his external behaviour that he goes along with the superstitions which pervert the service of God. During the course of his sermon Calvin answers this question clearly and unambiguously, teaching them the evangelical doctrine of the love and obedience they owe to God who has adopted them. Love and obedience are not as such stressed in the sermon but they are embedded beneath the surface. They are, for instance, implied in the loyalty to our "true confession of faith". Note also the remark that the worship of the golden calves repugne à la doctrine de la Loy (CO 8,383), which implies that every kind of idolatry is disobedience. Cf. 1 Samuel 15:23.

It would therefore be a misunderstanding to view this sermon (perhaps the most vehement of the four) as nothing but a tirade against Roman Catholicism. ${ }^{16}$ According to the superscript of the preface the Four Sermons are addressed "to all true Christians who desire the advancement of the reign of our Lord Jesus Christ". ${ }^{17}$ In the first sermon Calvin specifically treated the existential question of Protestants in Roman countries, refuting their double-mindedness and their consequent subterfuges and urging them to live according to their confession.

\section{Conclusions}

- Calvin's eloquent style and harsh, "correctional" language reveal, in Parker's words, the pastoral impulsion (Parker, 1992:8). By these means he warns against the coming judgement of God; he proclaims the Word in such a way as to draw double-minded Protestants out of their vices and to tear them away from the wrath of the God of truth.

- The anthropological aspect, shown in this sermon by Calvin's accent on the body, is of special import. In his Institutes Calvin, a man with many ailments, sometimes refers to the body as a "prison". ${ }^{18}$ These and other remarks in the same vein have led to a host of speculations about Plato's influence on Calvin. Thus Stuart Fowler (1984:339-352) write about "The persistent dualism in Calvin's thought", while other scholars see a spiritual tendency or an ambivalence toward the body in Calvin's theology (see for instance the excellent overview with recent literature of Davis, 1994:406-418). This sermon is a wholesome correction of these ideas. In view of Calvin's strong

16 Some of Calvin's adversaries blamed him for doing nothing but to shout against the papists (see for particulars Peter, 1984:25).

17 CO 8, 374. The topicality of these sermons can be seen in their translations: the first Latin translation appeared in 1553 (a year later than the original), a reprint in 1556; the first English translation in 1561, a second in 1579 (cf. Parker, 1992:187-188). 
accent on the body, and elsewhere on the true and full humanity of Christ, on which our salvation depends, it is doubtful whether one can even speak of an ambivalence toward the body. Note the strong accent of Calvin on the vicarious humanity of Christ (Torrance, 1978:69-84).

- The sermon also contains an ecclesiological dimension to which Calvin alludes by saying that those who take part in idolatrous superstitions estrange themselves from the "holy union" of Christ's members. This is stated more explicitly in the Commentary on the Book of Psalms (Calvin, 1979:220), where he says:

We cannot be united into the one body of the Church under God, if we do not break off all the bonds of impiety, separate ourselves from idolaters, and keep ourselves pure and at a distance from all the pollutions which comupt and vitiate the holy service of God

- The theological aspect of the sermon rests inter alia on the rejection of the Mass as an offering (sacrifice) of Christ to reconcile us to God. In Calvin's opinion this contradicts the atonement by the unique sacrifice of Christ on the cross, once and for all. This is the reason why he is so acrimonious in his sermon. The debate on offering or sacrifice concems the unique gracious work of God in Christ. This Christological dimension, the core of what we have termed the theological aspect, is of paramount importance, for the view of Christ's redemptive work has a bearing on the liturgy. Thus, in the medieval service, with the plenipotentiary priest in action, "our salvation is achieved through the performance of the liturgy" (Locher, 1981:8). But the view of Christ's work has also a bearing on what Calvin calls our service of God. Commenting on Zwingli's stress on the fulfilled atonement, Locher simultaneously sheds light on this sermon of Calvin. He writes,

This, therefore is the great change: the break-through from the liturgical and sacramental action of the church to the word of the completed atonement. The consequences of this for our understanding of everything that may in any sense be termed service of God are immeasurable All our service draws its life from the service that God has rendered to us. At the beginning of all our service stands the divine service of Jesus Christ, and that was a service of life, not a liturgy

The unique and gracious work of God concerns the truth of the Gospel and the promises of God. These must be embraced by faith. But faith excludes infidelity as well as superstition and directs our life and worship towards simplicity and integrity.

\section{Bibliography}

BENOIT, J.-D. ed 1963 Jean Calvin. Institution de la religion Chrestienne Vol. 5. Paris Librairie Philosophique J. Vrin. 
BEZA, Th 1958 The life of Calvin. (In Calvin's tracts and treatises. Grand Rapids Eerdmans p. 1Ivii-cxxxviii.)

CALVIN, J. 1552. Quatre sermons traictans des matieres fort utiles pour nostre temps, avec briefve exposition du Pseaume 87. Genève : Robert Estienne. (CO 8, 369-452)

CALVIN, J. 1864-1897. Ioannis Calvini opera quae supersunt omnia. Ed Baum, G., Cunitz, E. \& Reuss, E. Brunsvigae : Schwetschke et filium. Esp. vols. 6 and 8

CALVIN, J. 1958. Calvin's tracts and treatises on the reformation of the church. Transl. by $\mathbf{H}$. Beveridge Historical notes and introduction by T.F. Torrance. 3 vols. Grand Rapids Eerdmans.

CALVIN, J. 1962. Institutes of the Christian religion Transl. by H. Beveridge 2 vols Grand Rapids : Eerdmans.

CALVIN, J. 1979. Commentary on the Book of the Psalms Transl. by J. Anderson Repr Grand Rapids : Baker. (Calvin's Commentaries, vol. 4.)

CALVIN, J. 1994. Apology of John Calvin, to Messrs. the Nicodomites upon the complaint that they make of his too great rigour (1544). Transl. by Eric Kayayan. Calvin Theological Journal, 29:346-363, November.

$\mathrm{CO}$

See

Ioannis Calvini opera quae supersunt omnia.

DAVIS, T.J. 1994. Not 'hidden and far off': The bodily aspect of salvation and its implications for understanding the body in Calvin's theology Calvin Theological Joumal, 2406-418, November.

DOUMA, J \& VAN DER VEGT, W.H. 1941. Het gepredikte Woord. Vol. 5 Franeker Wever. p. 11-30.

FOWLER, S. 1984. The persistent dualism in Calvin's thought. (In Our Reformational tradition. Potchefstroom : IRS, PU for CHE. p. 339-352 )

HUGHES, P.E. 1966. Introduction. (In The register of the company of pastors of Geneva in the time of Calvin. Grand Rapids : Eerdmans.)

LOCHER, G.W 1981. Zwingli's thought: New perspectives Leiden : Brill.

OPITZ, P 1997. Ein Thorapsalm als ABC des christlichen Glaubens. (In Neuser, W H., Selderhuis, H.J., Van 't Spijker, W. eds. Calvin's Books: Festschrift for Peter de Klerk Heerenveen : Groen p. 117-131)

PARKER, T H.L 1992. Calvin's preaching Louisville, Ky : Westminster

PETER, R 1984. Genève dans la prédication de Calvin (In Neuser, W H., ed. Calvinus ecclesiae genevensis custos. Frankfurt a $M$ : Peter Lang p. 23-48.)

PIGHIUS, A. 1542. De libero hominis arbitrio et divina gratia libri X Cologne : Melchior Novesianus.

$\mathrm{RCP}$

See

The register of the company of pastors of Geneva in the time of Calvin. Ed and transl by P.E. Hughes Grand Rapids : Eerdmans.

TORRANCE, J.B. 1978 The vicarious humanity and priesthood of Christ in the theology of John Calvin. (In Neuser, W H., ed. Calvinus ecclesia doctor. Kampen : Kok. p 69-84.)

TORRANCE, T.F, 1958. Introduction. (In Calvin's tracts and treatises, vol. 1. Grand Rapids : Eerdmans p. 352.)

WALLACE, Ronald, S. 1988 Calvin, Geneva and the Reformation. Grand Rapids : Baker WILLIAMS, George H 1962. The Radical Reformation. Philadelphia, Pa : Westminster Press. 